\title{
Title: Is the Final Chapter of the Metaphysics of morals also the Final Chapter of the Practical Postulates?
}

Abstract. In this paper I trace the arc of Kant's critical stance on the belief in God, beginning with the Critique of Pure Reason (1781) and culminating in the final chapter of the Metaphysics of morals (1797). I argue that toward the end of his life, Kant changed his views on two important topics. First, despite his stinging criticism of it in the Critique of Pure Reason, by the time of the Metaphysics of morals, Kant seems to endorse the physico-theological argument. Second, some time around the publication of the Metaphysics of morals, Kant seems to move away from the argument for the practical postulates.

In this paper I trace the arc of Kant's critical stance on the belief in God, beginning with the Critique of Pure Reason (1781) and culminating in the "Doctrine of the methods of ethics," the final chapter of the Metaphysics of morals (1797). ${ }^{\mathrm{i}}$ I argue that it is only by examining closely the "Doctrine of the methods of ethics" that we can appreciate a fundamental shift in Kant's views on the existence of God, a shift that has

gone unnoticed in recent discussions because of the relative neglect of the Metaphysics of morals and especially of the final chapter of this work.

One of the things in the Critique of Pure Reason for which Kant became famous was his attack on traditional arguments for the existence of God. He begins by dividing these arguments into three kinds: (1) ontological arguments, based solely on the concept 
of God, (2) cosmological arguments, based solely on the existence of a world, and (3) physico-theological arguments, based on the particular constitution of the actual world. Kant then subjects each of these arguments to withering criticisms, criticisms that some think earned him the name "the all-destroying Kant" from Moses Mendelssohn $(1729-1786) .{ }^{\text {ii }}$

However, Kant also puts forth a positive argument for the existence of God in the Critique of Pure Reason. In broad strokes, the argument goes like this: (1) morality commands us to realize a world in which we are perfectly virtuous and in which happiness is doled out in accordance with virtue; (2) it is rational to try to realize something only if it has a ground in reality; (3) the world that morality commands us to realize can have a ground in reality only if God exists (and the soul is immortal); and therefore (4) to fulfill the commands of morality we must bring ourselves to believe in God. Kant concludes from this that the existence of God is a "practical postulate."'iii Both Kant's negative arguments and his positive arguments for the existence of God have been the subject of much controversy in the secondary literature. Recent debates have been spurred on by Wood, who has given detailed, book-length assessments of Kant's criticism of the ontological argument and of Kant's practical postulates (in Kant's Rational Theology and Kant's Moral Religion, respectively). One of the things that is notable about Kant's practical postulates and that is brought out especially in the work of Guyer on this subject is the evolution of the arguments. Kant sets forth the practical postulates in all three Critiques as well as in many of his other major works. But the articulations of the arguments are often subtly different. Nonetheless, the general 
contours of the arguments remain the same. This suggests that although Kant was not entirely satisfied with the details of the arguments, he continued to think that any difficulties therewith could be smoothed out, that the arguments, and especially the argument about God, could be made to work. Such, anyway, seems to be the general consensus on this subject in the secondary literature.

However, I argue that a close inspection of the last chapter of the Metaphysics of morals reveals otherwise. In fact, a close reading of this under-utilized text reveals that toward the end of his life, Kant changed his views on two important topics. First, despite his stinging criticism of it in the Critique of Pure Reason in 1781, by the time of the Metaphysics of morals, almost 20 years later, Kant endorses the physico-theological argument. Second, in the "Doctrine of the methods of ethics," Kant jettisons the argument for the practical postulates. Indeed, in the Metaphysics of morals, instead of arguing that morality commands us to do something that, in turn, requires us to believe in the existence of God, Kant argues that we have independent grounds for believing in the existence of God (to wit, the physico-theological argument) and therefore that it is rational to try to realize the kind of world that morality commands us to realize.

\section{The Critique of Pure Reason: Kant's Early Critical Views on the Physico-}

theological Argument Kant's Critique of Pure Reason criticism of the ontological argument is well known. He claims that the ontological argument presupposes that existence is a "real predicate,"iv which it is not (KrV, AA A598/B626). " Kant's argument for this claim is that when one thinks of a thing, one adds nothing to it by virtue of 
thinking of it as existing $\left(\mathrm{KrV}\right.$, AA A597/B625) ${ }^{\text {vi }}$ One of the reasons this criticism is so well known is that it has given rise to a series of modern debates, like the debate about negative singular existentials. ${ }^{\mathrm{vii}}$ I do not intend to take a stand on whether Kant is right. ${ }^{\text {vii }}$ It hopefully will suffice merely to point out that the ontological argument, which usually is traced back to Anselm's version of it in his Proslogion, and criticisms of the argument, which arguably begin with Gaunilo's response to Anselm, continue to be an area of exploration today. ${ }^{\mathrm{ix}}$

Kant's attack on the cosmological argument is multipronged. ${ }^{\mathrm{x}}$ First, he claims that even if the cosmological argument could establish the existence of some purposive being, it does not establish that this being has all the attributes the theists want to attribute to it. To establish that the being is a Supremely Perfect Being, the cosmological argument relies tacitly on the ontological argument, which Kant takes himself already to have defused (KrV, AA A606/B633-A609/B637; cf. KrV, AA A611/B639-A614/B642). Kant's argument for this relies on separating the inference to the existence of a sui generis being from the inference to the existence of an ens realissimum, a most real being $(\mathrm{KrV}$, AA A605/B633); the latter inference relies, according to Kant, on the ontological argument. ${ }^{\mathrm{xi}}$ However, Kant thinks that the first inference is subject to a suite of problems itself $(\mathrm{KrV}$, AA A609/B637-A610/B639). Describing those problems constitutes the second part of his attack on the cosmological argument (KrV, AA A609/B637-A610/B639). It is not my goal to establish that Kant's attack on the cosmological argument works. xii The cosmological argument, which is often traced back to Plato's Laws, continues to be an 


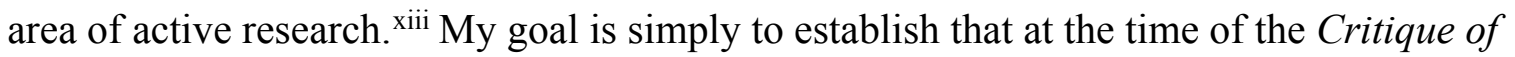
Pure Reason, Kant did not think that the cosmological argument worked.

For my purposes, Kant's most important remarks about proofs of God's existence come in his assessment of the physico-theological argument. ${ }^{\text {xiv }}$ The physico-theological argument, like the ontological argument and the cosmological argument, has a long history (it is often traced back to Plato) and still finds supporters today. ${ }^{\mathrm{xv}}$ Hume attacked the argument in his Dialogues Concerning Natural Religion. But the Dialogues Concerning Natural Religion was not published until 1779, and there was some delay in its translation into German. So it seems unlikely that Kant had read this work by the time of the publication of the Critique of Pure Reason. ${ }^{\mathrm{xvi}}$ The version of the physicotheological argument that Kant reconstructs in order to attack it runs as follows:

1) Everywhere in the world there are clear signs of an order according to determinate aim, carried out with great wisdom, and in a whole of indescribable manifoldness in content as well as of unbounded magnitude in scope. 2) This purposive order is quite foreign to the things of the world, and pertains to them only contingently, i.e., the natures of different things could not by themselves agree in so many united means to determinate final aims, were they not quite properly chosen for and predisposed to it through a principle of rational order grounded on ideas, 3) Thus there exists a sublime and wise cause (or several), which must be the cause of the world not merely as an all-powerful nature working blindly through fecundity, but as an intelligence, through freedom. 4) The 
unity of this cause may be inferred from the unity of the reciprocal relation of the parts of the world as members of an artful structure, inferred with certainty wherever our observation reaches, but beyond that with probability in accordance with all principles of analogy.

(KrV, AA A625/B653-A626/B654)

The basic idea behind this argument is that we can see "clear signs" of purposive order in the world, and a purposive order presupposes a purposeful creator.

Kant criticizes this argument on three fronts. First, he points out that the physicotheological argument warrants at most the conclusion that there is a highest architect of the world, not a highest creator (KrV, AA A627/B655). The idea is that the physicotheological argument begins with a premise about the particular way in which the world has been put together. It does not begin with a premise about the particular substance from which the world is made. Accordingly, the strongest conclusion warranted is that there was a purposeful architect of the world. But this architect might have been limited in what s/he could do by the materials available. Indeed, the inference that the world is purposive and therefore must have a purposeful designer proceeds by analogy with human artifacts. But when humans design and build things, they are limited by the materials available to them. So even if we could have insight into whether the substance of the world was chosen by design (we cannot on Kant's account, but even if we could) the analogy that is central to the physico-theological argument can support only the inference to a highest architect. 
Kant's second criticism of the physico-theological argument is that the argument does not warrant inferring the existence of any determinate being much less an all-perfect one (KrV, AA A628/B656). The idea here is that our insight into the world does not (and cannot) warrant concluding that the designer of the world is all-perfect, for we do not know (amongst other things) whether this is the best of all possible worlds. Or, more accurately, if we do know that this is the best of all possible worlds, we do not learn that it is so from looking around. Therefore, we are not warranted in concluding that the architect of the world is the best of all possible architects simply by looking around.

Kant's third and final objection to the physico-theological argument is that it makes a hidden appeal to the cosmological argument, which in turn makes a hidden appeal to the ontological argument (KrV, AA A629/B657-A630/B658). Kant says that proponents of the physico-theological argument infer the existence of an all-perfect creator of the world despite the fact that, as his previous two objections show, they are not warranted in so doing. He concludes that they must be making a tacit appeal to the cosmological argument. Because both the cosmological argument and the ontological argument on which the former (supposedly) depends already have been seen to fail on Kant's account, he concludes that the physico-theological argument does not work.

This concludes my examination of Kant's Critique of Pure Reason criticisms of the traditional arguments for the existence of God in general and of the physicotheological argument in particular. I am not going to assess the philosophical plausibility of Kant's arguments. ${ }^{\text {xvii }}$ The main thing to see from this is that in the Critique of Pure Reason, Kant was arguing against the physico-theological argument. I turn now to the 
Critique of Pure Reason doctrine of the practical postulates and, in particular, the postulate of the existence of God.

II.

\section{The Critique of Pure Reason: Kant's Early Critical Views on the Practical}

Postulate of the Existence of God Kant's Critique of Pure Reason argument for the practical postulates occurs in the second section of the "Canon of Pure Reason." xviii The basic argument rests on an inference that something is so because it ought to be so $(\mathrm{KrV}$, AA A806/B834).xix That is, as Kant represents it, the crux of the argument rests on the use of the "ought implies can" principle: because we ought to X, we must be able to X, and for $\mathrm{X}$ to be possible, it must have a ground in actuality. ${ }^{\mathrm{xx}}$

The argument begins with the claim that the moral law commands us to realize a moral world (KrV, AA A806/B836). A moral world is one that is in conformity with all moral laws; it is a world in which everyone's freedom has "thoroughgoing systematic unity in itself as well as with the freedom of everyone else" (KrV, AA A808/B836). But Kant says that a moral world is not yet the highest good; a moral world is incomplete.

A moral world is a world in which everyone is worthy of happiness. To complete the highest good, people who are worthy of happiness ought to be happy, and people who are unworthy of happiness ought not to be happy (KrV, AA A813/B841). Kant concludes, "happiness in exact proportion with the morality of rational beings... alone constitutes the highest good of a world into which we must without exception transpose ourselves" (KrV, AA A814/B842). 
Now if we ought to bring about a world in which the highest good is realized, then it must be possible to bring about such a world. But the only world of which the senses provide us any evidence is the world of appearances, so we must assume that the world will be brought about through our conduct in the sensible world. However, two problems arise here.

First, the highest good can be hoped for only if there is a highest reason that commands in accordance with the moral law and is the cause of nature $(\mathrm{KrV}, \mathrm{AA} A 810$ / B838). The idea here is that the conjunction of the systematic unity required by a moral world with the systematic distribution of happiness is extremely complicated. It is so complicated that it rationally can be believed to be possible only if there is a God and, in particular, a God who has engineered the world in such a way that good behavior will be consummated with happiness (and bad behavior with unhappiness). ${ }^{x i}$ The main reason this conjunction is so complicated seems to be that people do not always act in accordance with the moral law. Because people do not always act morally, the ultimate distribution of happiness does not depend merely on the laws of nature or merely on the causality of actions themselves and their relation to morality ( $\mathrm{KrV}$, AA A810/B838). One of the underlying ideas here might be that bad people often get in the way of the carrying out of the best intentions. So if the moral law commands us to realize the highest good, we must constrain ourselves (on pain of irrationality) to believe in a God who corrects for this.

Second, given what we have seen of the world thus far, it is extremely improbable that the world is so happily constituted. Therefore, the belief in God and, thus, the 
rationality of pursuing the highest good can be maintained only if there is a future life (KrV, AA A811/B839). To simplify, the idea seems to be something like this: belief in God is necessary but not sufficient to make rational the pursuit of the highest good. The problem is that there is too much countervailing evidence; there is too much evidence that the highest good will not be realized. Vicious people are often happy; virtuous people often suffer. So we must constrain ourselves (on pain of irrationality) to believe that there is a future life. It is in the future life that the highest good actually will be realized. ${ }^{x x i i}$

It is perhaps worth wondering whether Kant can give a justification for his appeal to "ought implies can" in this argument. That is, it is perhaps worth wondering whether Kant can justify inferring that we must be able to pursue the highest good because we ought to (and therefore that we ought to believe in God and a future life) rather than the other way around (that we have no duty to promote the highest good because its realization is impossible). ${ }^{\mathrm{xxii}}$ But as in the previous section, my goal in this section is not to assess the philosophical plausibility of Kant's arguments. ${ }^{x i v}$ The main goal is simply to see that in the Critique of Pure Reason Kant thinks that we ought to believe in the existence of God because morality commands us to pursue an end that we rationally can believe to be possible only if God exists.

III.

The Critique of Practical Reason and the Critique of the Power of Judgment: Kant's Evolving Views on the Practical Postulate of the Existence of God and the Physico-theological Argument Kant's views on the practical postulates and on the physico-theological argument evolved over the course of time. This can be seen in the 
Critique of Practical Reason, published in 1788, only one year after the second edition of the Critique of Pure Reason. It also can be seen in the Critique of the Power of Judgment, published two years later in 1790 .

The Critique of Practical Reason contains Kant's most systematic exposition of the practical postulates. The basic structure of the argument remains the same: it infers that something is the case because something ought to be the case. However, the particular justifications for the practical postulates have changed. Now the postulate of immortality is needed to guarantee the possibility of moral perfection instead of the possibility of happiness in proportion to morality. The idea is that as sensible beings, humans cannot attain holiness, complete conformity of the will with the moral law, which is what the highest good requires. The best we can do is an infinite progression toward holiness, and for this we need an infinite time and, hence, immortality (KpV, AA 5:122-123). ${ }^{\mathrm{xx}}$ The postulate of the existence of God is needed to guarantee the possibility of the distribution of happiness being proportional to virtue. The idea is that the only way there could be a necessary connection between virtue and happiness is if there were an omnipotent, omniscient, all-benevolent God who created nature and its laws $(\mathrm{KpV}, \mathrm{AA}$ 5:124-6). ${ }^{\mathrm{xxvi}}$ This argument is repeated in the Critique of the Power of Judgment (KU, AA $5: 450)$.

The other thing that has changed is Kant's attitude toward the physico-theological argument. To be sure, even in the Critique of Pure Reason Kant did not seem to regard the physico-theological argument as resting entirely on "sophistry," as he regards the other two arguments by the time of the Critique of the Power of Judgment (KU, AA 
5:476). Even in the Critique of Pure Reason Kant tells us that the physico-theological argument "always deserves to be named with respect" (KrV, AA A623/B651). The point of the objections to the physico-theological argument discussed above is to "tone down the language of a scornful sophist to the tone of moderation and modesty of a belief that is sufficient to comfort us" (KrV, AA A624/B652). Nonetheless, Kant's change in attitude toward the physico-theological argument can be seen in two ways.

First, in the Critique of the Power of Judgment Kant supports rather than attacks the physico-theological argument. For example, he claims that reflective consideration of nature certainly will give us "sufficient reason" to infer the existence of an intelligent designer (KU, AA 5:439); that the physico-theological proof furnishes us with the concept of a highest understanding as world-cause "completely in according to principles of the reflecting power of judgment, i.e., in accordance with the constitution of our (human) cognitive faculty" (KU, AA 5:476); and that inferring an intelligent designer "from the great purposiveness of natural forms and their relation" is justified (KU, AA 5:480). To be sure, he does not think that we are warranted in this way in inferring the existence of a "supreme, i.e., intelligent independent being" (KU, AA 5:476). But he does think that the physico-theological argument is successful in taking us "beyond the boundaries of nature as the sum of objects of the senses" despite its empirical starting point (KU, AA 5:476).

Second and more striking, Kant now brings the physico-theological argument and the practical postulate of the existence of God together. The following passage is illustrative: 
...the fact that rational beings in the actual world find ample material for physical teleology there (although this was not necessary) serves as the desired confirmation of the moral argument, insofar as nature is thus capable of displaying something analogous to the (moral) ideas of reason.

(KU, AA 5:479)

Thus, the physico-theological argument has a positive role now: it bolsters up the moral argument provided by the practical postulate of the existence of God. The practical postulate would stand on its own, but the physico-theological does give a desired confirmation of the postulate. And the relationship between the physico-theological argument and the practical postulate of the existence of God is not a one-way street; it is mutualistic. The physico-theological argument gives evidence for the rectitude of the practical postulate, and the practical postulate completes the physico-theological argument. ${ }^{\text {xxvii }}$ In particular, the practical postulate fills the gap that in the Critique of Pure Reason was filled by the cosmological argument. Let me explain.

Recall that in the Critique of Pure Reason, Kant concluded that because the physico-theological argument does not warrant inferring the existence of a supreme, allperfect God, supporters of the physico-theological argument must make a tacit appeal to the cosmological argument. Now in the Critique of the Power of Judgment, the move from inferring the existence of an intelligent designer to inferring the existence of a supreme, all-perfect God is made by means of the practical postulate of the existence of God: 
If one minimizes the problem that a physicotheology is supposed to solve, then its solution seems easy. That is, if one reduces the concept of a deity to that of an intelligent being that can be conceived by us... then physical teleology can make significant claims to the distinction of establishing a theology. But if it is demanded that we show what drives us and even justifies us in adding those supplements [such as all-perfect to the concept of this deity]... on closer examination we would see there actually lies in us $a$ priori an idea of a highest being, resting on a very different use of reason (its practical use), which drives us to amplify physical teleology's defective representation of the original ground of the ends of nature...

To summarize: Kant's ideas about the physico-theological argument and about the practical postulate seem to shift between the Critique of Pure Reason, published in 1781, the Critique of Practical Reason, published in 1788, and the Critique of the Power of Judgment in 1790. In the Critique of Practical Reason, we see Kant justifying the postulate of immortality on the grounds that we need an infinite amount of time to attain moral perfection-a marked shift from the Critique of Pure Reason argument, which seems to justify immortality on the grounds that it is required for the distribution of happiness in the highest good to be realized. In the Critique of the Power of Judgment, we see Kant endorsing the physico-theological argument, albeit within very strict confines. More striking and more relevant for my purposes, we also see Kant putting the physico-theological argument together with the practical postulates in a way that could 
not have been foreseen based on the discussions in the Critique of Pure Reason and the Critique of Practical Reason. On the one hand, the physico-theological argument now provides empirical confirmation for the moral argument in the practical postulates. On the other hand, the practical postulates now shore up the gap in the physico-theological argument in its inference of the existence of an all-perfect God from the purposiveness in nature-a gap that in the Critique of Pure Reason was filled by the sophistical cosmological argument and, thereby, the equally sophistical ontological argument.

IV.

\section{0-1797: Filling the Gap Between the Critique of the Power of Judgment}

and the Metaphysics of morals There are two things to which I would like to draw attention with regard to Kant's intellectual development between 1790 and 1797. The first is Kant's seeming ambivalence toward the postulate of immortality.xxviii This can be seen already in the Critique of the Power of Judgment. For example, in the section on ethicotheology (§86) Kant explains in detail how God’s existence and different properties (omnipotence, omniscience, etc.) can be argued for based on moral considerations about the highest good but does not even mention immortality (KU, AA 5:442-5).xxix Indeed, whereas the postulate of the existence of God has its own section (§87) the treatment of the postulate of immortality is largely unexplained, relegated to a few cursory lines. ${ }^{\mathrm{xxx}}$

However, Kant's relative neglect of the postulate of immortality is even more marked in his 1793 Religion within the Boundaries of Mere Reason. In the opening pages of this work, Kant rehearses the argument for the postulate of the existence of God without so much as a hint at the postulate of immortality. He tells us about 
...the idea of a highest good in the world, for whose possibility we must assume a higher, moral, most holy, and omnipotent being who alone can unite the two elements of this good.

(RGV, AA 6:05)

Here Kant tells us that the possibility of the highest good requires assuming the existence of an omnibenevolent, omnipotent God who can ensure that happiness and virtue (the "two elements" in this quotation) are distributed proportionately. But he does not tell us in this passage that the possibility of the highest good requires assuming also the existence of a future world: the postulate of immortality is left unaccounted for. Indeed, Kant tells us that the postulate of the existence of God is needed for the realization of the highest good in "this world" (my emphasis) both in the quotation above and in a footnote appended to the passage from which the quotation above is excerpted, a footnote in which he spells out the argument for the postulate of the existence of God in more detail (again without mention of the postulate of immortality). ${ }^{\mathrm{xxxi}}$

Even more interesting, in part two of the Religion within the Boundaries of Mere Reason Kant seems to repudiate his 1788 Critique of Practical Reason argument for the postulate of immortality (noted above). Recall that according to this argument immortality must be assumed in order to make possible the moral perfection enjoined by the moral law. But at RGV, AA 6:65-8, Kant tells us that a change in disposition is sufficient for moral goodness and therefore "notwithstanding his permanent deficiency, a human being can still expect to be generally well-pleasing to God, at whatever point in time his existence be cut short" (RGV, AA 6:67). 
Similarly, at RGV, AA 6:73-6, only a few pages later in the Akademie edition, Kant seems to turn against his 1781 Critique of Pure Reason argument for the postulate of immortality (also noted above). Recall that according to this argument immortality must be assumed in order to ensure that happiness is distributed in accordance with virtue. But in this section of the Religion within the Boundaries of Mere Reason, Kant claims that moral evil requires infinite punishment from an omnipotent lawgiver and then goes on to ask

... whether, by means of the very concept of moral conversion, we can think that situation as entailing such ills as the new human being, whose disposition is good, can regard as having been incurred by himself (in a different context) and, [therefore], as punishment whereby satisfaction is rendered to divine justice.

(RGV, AA 6:73-4)

Kant is asking whether moral conversion on his (new) theory renders obsolete the rationale he advanced for the postulate of immortality in the Critique of Pure Reason-and he goes on to argue in this passage that it does.

Kant's seeming ambivalence to the postulate of immortality as documented here is perhaps less surprising when considered in light of what he says in some of his unpublished work. For example, in R8101, Kant claims that although we must believe in God and a future life out of a moral need, the faith that is thereby engendered in the immortality of the soul "is only a belief in the second rank. For it is not necessary that we exist... eternally, but only that so long as we live we conduct ourselves so as to be worthy 
of life" (Refl, AA 19:644). ${ }^{\text {xxii }}$ It is notable that R8101 is usually dated to just this period of Kant's life.

However, if we trust Kant's students' transcriptions of his metaphysics lectures as accurate representations of Kant's own views, then Kant's doubts about the postulate of immortality can be seen to predate this reflection. For example, in his 1783 lectures on metaphysics, Kant objects to the idea that a distribution that balances happiness in accordance with morality requires assuming the immortality of the soul. He argues that for some, this balance might be met in this life; for others, it might not be met in this life, but it might require only an additional 100 years or so rather than an eternity:

But if we allow a future compensation it does not at all follow that this will be eternal. Now can we actually demand an eternal reward for our few virtues? And if we also wanted to have a myriad of years which then would pass, how would that help us? Finally, this proof also shows only that the future life will be particular. For children, idiots, and the wholly stupid, people whose lives are neither morally worthy nor morally unworthy, are excluded according to this proof, or at least are not included in it.

(V-Met/Mron, AA 29:917)

Curiously, Kant goes on in the next pages of this passage to propose an entirely new argument for the postulate of immortality. That is, Kant says in these pages that the practical postulate of immortality attaches to the idea that if there were no immortality, then the moral law would have insufficient incentive: 
That human beings are bound to act honestly and to be good is an apodictic proposition. Only immortality can provide incentives for this. Therefore it is a practical postulate that the soul is immortal... Although this cannot be counted among the scientific proofs, for all that it has strength. For with it I bring the opponent to a practical absurdity $<a d$ absurdum practicum>.

(V-Met/Mron, AA 29:918-9)

Of course, it must be remembered that these lecture notes were not written by Kant himself. But this attack on the idea that immortality is needed to ensure that happiness is distributed in proportion to virtue is not unique to the Mrongovius lecture notes on metaphysics. The same attack (the attack hinging on the claim that for some, the balance of happiness or virtue is met in this life while for others it might require only a finite rather than an infinite afterlife) can be found in the $\mathrm{L}_{1}$-Pölitz lecture notes on metaphysics (V-Met-L1/Pölitz, AA 28:289-91) and also in the $\mathrm{K}_{2}$-Heinze lecture notes on metaphysics (V-Met-K2/Heinze, AA 28:767). ${ }^{x x x i i i}$ The fact that the attack shows up repeatedly lends credence to the idea that it is representative.

However, Kant continued to play with the argument for the postulate of immortality in his unpublished reflections from around the time of the Religion within the Boundaries of Mere Reason. For example, in R6432, which is usually dated to 1790-5, Kant argues as follows: 
This law [viz., the moral law] as a principle of wisdom leads our reason in its practical use to the final end of a highest wisdom: the greatest happiness combined with virtue as the final end of all things, which, however, so far as we can see makes necessary an eternity of our existence and a moral author of the world for realizing the constitution of the world that is requisite for that.

(Refl, AA 18:714) $)^{\mathrm{xxxiv}}$

Moreover, by 1796 Kant seems to have regained faith in the postulate of immortality (at least temporarily). This can be seen by appeal to his Proclamation of the imminent conclusion of a treaty of perpetual peace in philosophy. For example, in a section titled “On the Super-sensible Objects of Our knowledge," Kant argues that these objects include "immortality, as a state in which man's weal or woe is to be allotted to him in proportion to his moral worth" (VNAEF, AA 8:418). Of course, it should be noted that this claim hearkens back to the argument made in the Critique of Pure Reason, perhaps signifying Kant's enduring dissatisfaction with the Critique of Practical Reason argument about perfect virtue requiring immortality (eschewed in the Religion within the Boundaries of Mere Reason). But the point is that Kant seems unambiguously to be committing himself to the postulate of immortality in his published work as late as 1796 .

Plainly more could be said about Kant's attitude to the postulate of immortality in the 1790s. But I would like to put that down for now and to pick up another thread, the second thing to which I mentioned I would like to draw attention in the opening paragraph of this section. As noted in the previous section of this paper, in the 1790 
Critique of the Power of Judgment we see Kant putting the physico-theological argument and the postulate of the existence of God together. The conjunction of these two arguments is, on Kant's account, a happy one: the two arguments prop each other up.

I simply would like to point out that Kant continued to play with this idea in both his unpublished and his published writing after the 1790 publication of the Critique of the Power of Judgment. For example, in R6451, which is usually dated to 1790-5, Kant tells us that the physico-theological argument works together with the moral argument for the postulate of the existence of God. The first establishes a being of great perfection; the second establishes that this being is a moral being:

First, the representation for the world as a system of the nexus finalis physici... Thus a rational primordial being, but not yet God, since the concept of the perfection of the world drawn from experience does not suffice for that. Now, the representation of the world as a system of final moral causes [systematis caussarum finalium moralium] ${ }^{\mathrm{xxv}}$ for the highest good. For the human being, who is a member of the nexu finalis physico, but who finds in himself a principle of the higher nexus finalis, will also relate his existence with respect to that higher nexus to that same rational author... Thereby is the assumption of a living God as a moral being and thus also as an all-sufficient being accepted.

(Refl, AA 18:723)

Even more decisively, in his 1791 On the Miscarriage of all Philosophical Trials in Theodicy Kant makes a similar claim in an important footnote: 
... when art proves itself adequate to ideas the possibility of which surpasses every insight of human reason (e.g. when means and ends reciprocally produce one another, as in organic bodies), as a divine art, it can also, not incorrectly, be given the name of wisdom... Teleology (and, though it, physicotheology) gives abundant proof in experience of this artistic wisdom. But from it no inference is allowed to the moral wisdom of the author of the world, for the natural law and the moral law require principles of entirely different kinds... the proof of the existence of such a being [viz., a moral being] can be none other than a moral proof.

(MpVT, AA 8:256n)

This concludes my discussion of Kant's views on the practical postulates from 1790 to 1797 (the period between the publication of the Critique of the Power of Judgment and the Metaphysics of morals). In this section I tried to draw attention to two things: Kant's growing ambivalence toward the postulate of immortality (as borne out especially in the Religion within the Boundaries of Mere Reason and his unpublished reflections) and Kant's continued experimentation regarding the relationship between the physicotheological argument and the postulate of the existence of God (as borne out in his unpublished reflections and On the Miscarriage of all Philosophical Trials in Theodicy).

Finally, it should be realized that Kant commits himself explicitly to both the postulate of the existence of God and the postulate of immortality as late as 1796 (in On the Miscarriage of all Philosophical Trials in Theodicy). However, as we shall see in the final section of this paper, evidence of Kant's break with these arguments (or with the 
postulate of the existence of God, anyway) can be found as early as his Metaphysics of morals, published less than five years after On the Miscarriage of all Philosophical Trials in Theodicy.

$\mathrm{V}$.

\section{The Final Chapter of the Metaphysics of morals: the Final Chapter of the}

Practical Postulates Kant's Metaphysics of morals originally was published in two parts, the Doctrine of Right and the Doctrine of Virtue. The Doctrine of Right appeared sometime around January of 1797 . The Doctrine of Virtue appeared sometime around August of the same year. The Metaphysics of morals, which combines these two works, appeared in 1798 with some minor revisions. The revisions were mainly to the Doctrine

of Right and do not concern us here. ${ }^{\mathrm{xxxvi}}$ For the purposes of this paper, my interests lie in the final chapter of the Metaphysics of Morals, which is also the final chapter of the Doctrine of Virtue. This chapter is called the "Doctrine of the methods of ethics." It is in parallel with the "Doctrine of the method of pure practical reason," the final chapter of the Critique of Practical Reason.

In the "Doctrine of the methods of ethics," Kant tells us how to teach some of the basics of ethics to children. He envisions a pupil and a teacher in a conversation. The teacher does not lecture to the student about abstract moral truths or applied ethics. But the teacher also does not engage the student in a dialogue of equals, for the student must be guided. The teacher presents the pupil with questions and, in doing so, the teacher guides and gives form to the pupil's thoughts, thereby becoming "the midwife of the 
pupil's thoughts" (MS, AA 6:478). Kant writes out a fragment of what he imagines would take place in such an interview. The following passage is taken from the end:

Teacher: ...even if we are conscious of such a good and active will in us, by virtue of which we consider ourselves worthy (or at least not unworthy) of happiness, can we base on this a sure hope of happiness?

Pupil: No, not on this alone. For it is not always within our power to provide ourselves with happiness, and the course of nature does not of itself conform with merit. Our good fortune in life (our welfare in general) depends, rather, on circumstances that are far from all being in our control. So our happiness always remains a wish that cannot become a hope, unless some other power is added.

Teacher: Has reason, in fact, any grounds of its own for assuming the existence of such a power, which apportions happiness in accordance with a human being's merit or guilt, a power ordering the whole of nature and governing the world with supreme wisdom? That is, any grounds for believing in God?

Pupil: Yes. For we see in the works of nature, which we can judge, a wisdom so widespread and profound that we can explain it to ourselves only by the inexpressibly great art of a creator of the world. And with regard to the moral order, which is the highest adornment of the world, we have reason to expect a no less wise regime, such that if we do not make 
ourselves unworthy of happiness, by violating our duty, we can also hope to share in happiness.

(MS, AA 6:482)

Now I want to spend some time with this passage because it is important to realize exactly what is going on. The teacher brings the pupil around to the concept of justice. Justice is understood here in terms of moral desert. Happiness should be meted out in accordance with worthiness for that happiness. To behave morally just is to make oneself worthy of happiness. These ideas should be familiar by now. A world in which everyone receives his or her moral desert is a world in which the highest good is realized.

At this point, the teacher asks the pupil whether we can be certain that good behavior brings with it in itself a guarantee of happiness (and bad behavior one of unhappiness). The pupil responds that it does not. The pupil points out that our happiness depends on factors that are beyond our control. Thus, the pupil concludes, unless there is a God, we can have no grounds for hoping that happiness and worthiness for that happiness will go together in the world. However, the teacher presses on, asking whether there are any grounds for believing in God and, therefore, in the real possibility of a world in which there is such a distribution of happiness.

We might expect Kant's pupil here to begin talking about the duty to promote the highest good. That is, the argument we would expect given Kant's discussion of the practical postulates is something like this: there is a duty to realize this kind of distribution, so it must be possible. It is a real possibility only if there is a God. So in 
order rationally to fulfill the duty to realize this kind of distribution, belief in God is required.

However, that is not what the pupil answers. Instead, the pupil appeals to the physico-theological argument: the pupil says that the purposiveness we observe in the world warrants inferring (indeed, can be explained only by inferring) the existence of a God. Then the pupil winds things up by arguing that there is no reason to suppose that this wise and benevolent God, whose existence can be inferred from the physicotheological argument, does not govern also the moral sphere. Thus, the physicotheological argument gives us a presumptive ground for hoping that the distribution of happiness required for the highest good is a real possibility.

In other words, Kant has turned on its head his earlier line of reasoning. In the Critique of Pure Reason, we saw Kant criticizing the physico-theological argument for the existence of God but nonetheless arguing that we ought to believe in the existence of God on the basis of the practical postulates. ${ }^{\text {xxxii }}$ In the Critique of the Power of Judgment, we saw Kant again pointing out the limitations of the physico-theological argument-but we also saw him saying that it can bolster the practical postulates. Finally, by the last chapter of the Metaphysics of morals, we see Kant resting the hope that was justified previously by appeal to the practical postulates-that is, hope in the real possibility of the distribution of happiness required for the realization of the highest good-entirely on the physico-theological argument.

What can we conclude from this? Can we conclude that by the time of the Metaphysics of morals Kant had given up on the line of reasoning in the practical 
postulates and had become complacent about the shortcomings he earlier had found in the physico-theological argument? If the passage cited above were the only one we had to go on, this conclusion, I think, would be unwarranted. For one thing, Kant does not explicitly say in this passage that he has foresworn the line of reasoning in the practical postulates. For another, it must be remembered that this is part of an imaginary dialogue between a teacher and a young pupil: perhaps Kant simply thought that the physicotheological argument is more appropriate for that context. However, there is more. In the conclusion of the "Doctrine of the methods of ethics," Kant advances a novel argument for the existence of God. It occurs in the following passage:

The ground on which a human being is to think of all his duties in keeping with this formal aspect of religion (their relation to a divine will given a priori) is only subjectively logical. That is to say, we cannot very well make obligation (moral constraint) intuitive for ourselves without thereby thinking of another's will, namely God's (of which reason in giving universal laws is only the spokesman). -But this duty with regard to God ... is a duty of a human being to himself, that is, it is not objective, any obligation to perform certain services for another, but only subjective, for the sake of strengthening the moral incentive in our own lawgiving reason.

(MS, AA 6:487)

This argument, like the practical postulate, is a moral argument for existence of God. But there is an important difference between this argument and the practical postulate for the 
existence of God. As we have seen, the practical postulate for the existence of God gets off the ground by virtue of the claim that the existence of God is necessary to guarantee the real possibility of a state of affairs that the moral law commands us to promote. The moral argument here, by way of contrast, gets off the ground by virtue of an appeal to human psychology. Kant thinks that if we reflect on the concept of obligation, we will be able to make it intuitive to ourselves only if we conceive of it as coming from some external source. But the only possible external source for the moral law is God. So in order to make rational carrying out the dictates of any obligation, we ought to bring ourselves to believe in the existence of God as the obligation-giver-as the lawgiver. The crucial difference between these two arguments is that in the practical postulate for the existence of God, Kant is arguing for God qua author of the laws of nature; in the present argument, Kant is arguing for God qua author of the laws of morality.

Thus it may be seen that Kant bypasses the practical postulate for the existence of God not once but twice in this section of the Metaphysics of morals. Moreover, in its stead he articulates an argument he previously had conjoined with it and a novel argument that has a similar starting point (morality). However, the decisive evidence of Kant's move away from the practical postulate for the existence of God comes in the Opus postumum, where Kant tells us, "there is only one practically sufficient argument for faith in one God... knowledge of all human duties as (tanquam) divine commands" (OP, AA 22:127). Kant makes two claims here. First, he claims that there is exactly one argument that is practically sufficient for faith in God: he claims that such an argument exists, and he claims that this argument is unique. Second, he tells us that this 
argument involves knowledge of human duties as divine commands: he tells us what this argument is-the one we just explored from the end of the Metaphysics of morals. So here we have Kant claiming explicitly that this argument-the argument involving knowledge of human duties as divine commands and not the practical postulate for the existence of God-is the only argument that is practically sufficient for faith in God. Needless to say, this entails that the practical postulate is insufficient.

Indeed, Kant returns again and again to this argument about knowledge of human duties as divine commands in the Opus postumum. Here are a few representative passages:

The principle of the knowledge of all human duties as (tanquam) universally valid commands, that is, in the quality of a highest, holy and powerful law-giver, raises the subject thought thereby to the rank of a single, powerful being: That is, the existence of such a being cannot be concluded from the idea which we ourselves think of God, but yet we may infer as [if] there were such a being...

The reality of the concept of freedom can, thus, only be presented and proved indirectly, through an intermediary principle, rather than directly (immediately). Likewise the proposition: "There is a God," namely, in human, moral practical reason, [as] a determination of one's actions in the knowledge of human duties as (as if) divine commands... 
In it, that is, the idea of God as a moral being, we live, move and have one being; motivated through the knowledge of our duties as divine commands.

(OP, AA 22:118)

...the supersensible is not an object of possible experience... but merely a judgment by analogy-that is, to the relational concept of a synthetic judgment, namely, to think all human duties as if divine commands and in relation to a person.

(OP, AA 22:120)

It can be seen from this that Kant is moving forward with the moral argument for the existence of God that he developed in the final section of the Metaphysics of morals and, more, that he has moved away from the postulate of the existence of God that he embraced in the Critique of Pure Reason, the Critique of Practical Reason and the Critique of the Power of Judgment.

I would like to close by noting that in addition to developing this new moral argument for the existence of God, in the Opus postumum Kant begins to develop an argument to prove the uniqueness of God. The uniqueness argument begins with the idea that God is all obligating but never obligated. If there were two such beings, then either neither would be all obligating or at least one would be obligated. In either case, there is a contradiction, so we may conclude that there is only one being that is all obligating but never obligated. Here is a representative passage in which Kant sketches this argument: A moral being who would be thought as obligating, but as obligated by no 
other, would be God. If such exists, then he is a single God; for to think of several of them is a self-contradiction, since they would be thought in a relation of obligation to one another.

(OP, AA 22:124)

This is not the place to explore this argument in detail. I note merely that Kant's interest in his new moral argument for the existence of God as a replacement for the practical postulate might have been bolstered by the fact that it dovetails so nicely with this uniqueness argument.

${ }^{\text {i }}$ For a good treatment of Kant's pre-critical stance on the belief in God, see Norbert Fischer and Maximilian Forschner (ed.'s), Die Gottesfrage in der Philosophie Immanuel Kants (Herder, 2010). This work also contains relevant material on Kant's critical stance on the belief in God.

ii In his biography of Kant, Kuehn reports that Kant feared losing his university post on account of his reputed atheism (Manfred Kuehn, Kant: A Biography (Cambridge University Press, 2001), p. 318). For a critical assessment of Kuehn's account of Kant's religiosity, see Stephen Palmquist, "Review-Kant: A Biography," Metapsychology online reviews 5.41 (2001).

iii For excellent exegeses of this argument (to which I am much indebted) see Paul Guyer, Kant on Freedom, Law, and Happiness (Cambridge University Press, 2000), chapter 10 and Allen Wood, Kant's Moral Religion (Cornell University Press, 1970). 
iv All translations of Kant's texts follow the Guyer/Wood Cambridge blue series translations. All citations are in accordance with standard practice: Akadamie Ausgabe pagination except for the Critique of Pure Reason, which is cited according to A/B pagination.

${ }^{v}$ Kant actually levels a few objections to the ontological argument. For a thorough discussion of this, see Dieter Henrich, Der ontologische Gottesbeweis. Sein Problem und seine Geschichte in der Neuzeit (Mohr, 1960); Charles Nussbaum, "Did Kant Refute the Ontological Argument?" Southwest Philosophy Review 10.1 (1994): 147-56; Edith and Klaus Düsing, "Negative und positive Theologie bei Kant. Kritik des ontologischen Gottesbeweises und Gottespostulat," in Societas rationis, edited by Dieter Hüning, Gideon Stiening and Ulrich Vogel (Duncker \& Humblot, 2002): 85-118; Allen Wood, Kant's Rational Theology (Cornell University Press, 2009); Chris Heathwood, “The Relevance of Kant's Objection to Anselm's Ontological Argument,” Religious Studies 47 (2011): 345-57; or Michael E. Cuffaro, "Kant and Frege on Existence and the Ontological Argument” History of Philosophy Quarterly 29.4 (2012): 337-54. 


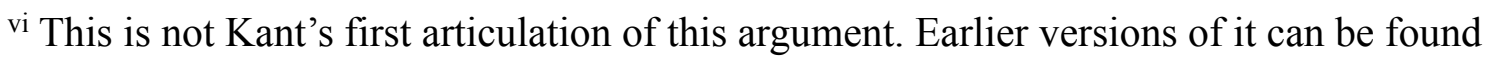
in his 1755 New Elucidation of the first Principles of Metaphysical Cognition (PND, AA 1:394-6) and in his 1763 The Only Possible Argument in Support of a Demonstration of the Existence of God (BDG, AA 2:70-7 and BDG, AA 2:156-7). There are also a number of reflections that shed light on Kant's thoughts here. For a small cross-section, see: R3706 (Refl, AA 17:240-243), R4659 (Refl, AA 17:628-629), R5255 (Refl, AA 18:133), R5506 (Refl, AA 18:202), R5507 (Refl, AA 18:203), R5523 (Refl, AA 18:207). See also Kant's 1817 (posthumously) published Lectures on the Philosophical Doctrine of Religion (V-Phil-Th/Pölitz, AA 28:1004-6).

vii See, e.g., Terence Parsons, Nonexistent Objects (Yale University Press, 1980).

viii For critical assessments of what Kant's negative and positive doctrines about religion leave for theology, see, e.g., Norbert Fischer, Kants Metaphysik und Religionsphilosophie (Meiner, 2004) or Georg Essen and Magnus Streit (ed.'s), Kant und die Theologie (Wissenschafliche Buchgesellschaft, 2005).

${ }^{\text {ix }}$ For the former, see, e.g., Alvin Plantinga, The Nature of Necessity (Oxford University Press, 1974). For the latter, see, e.g., Peter Millican, “The One Fatal Flaw in Anselm's Argument," Mind 113 (2004): 437-76.

x An earlier attack on this argument can be found in Kant's 1763 The Only Possible Argument in Support of a Demonstration of the Existence of God (BDG, AA 2:157-8). See also the Lectures on the Philosophical Doctrine of Religion (V-Phil-Th/Pölitz, AA 28:1006-7). 
${ }^{x i}$ For a negative assessment of this first part of Kant's attack, see John D. Caputo, "Kant's refutation of the Cosmological Argument," Journal of the American Academy of Religion 42.4 (1974): 686-91. For a competing view, see Donald P. Smith, "Kant on the Dependency of the Cosmological Argument on the Ontological Argument” European Journal of Philosophy 11.2 (2003): 206-18. For a more middle of the line view, see William F. Vallicella, "Does the Cosmological Argument Depend on the Ontological?" Faith and Philosophy 17.4 (2000): 441-58. xii For competing assessments of Kant's argument, see Everett J. Nelson, “Kant on the cosmological argument," Philosophical Review 44.3 (1935): 283-7; Peter Remnant, "Kant and the cosmological argument," Australasian Journal of Philosophy 37.2 (1959): 152-5; William H. Baumer, "Kant on Cosmological Arguments," The Monist 51.4 (1967): 519-35; or Herbert J. Nelson, "Kant on Arguments Cosmological and Ontological," American Catholic Philosophical Quarterly 67.2 (1993): 167-84.

xiii For a modern version of the cosmological argument, see Richard Gale and Alexander Pruss, The Existence of God (Ashgate, 2003). xiv An earlier attack on this argument can be found in Kant's 1763 The Only Possible Argument in Support of a Demonstration of the Existence of God (BDG, AA 2:92-155, especially 116-23). See also the Lectures on the Philosophical Doctrine of Religion (VPhil-Th/Pölitz, AA 28:1007-10 and 1063-71). 
${ }^{\mathrm{xv}}$ Its leading champion today is Michael Behe, who coined the term 'irreducible complexity' to describe biological systems that are so complex that they could not have evolved from simpler systems through natural selection (Michael Behe, Darwin's Black Box: The Biochemical Challenge to Evolution (The Free Press, 1996)). Paley put forth what has become probably the most famous version of the physico-theological argument two years before Kant's death in his 1802 Natural Theology. In his 1887 autobiography, Darwin tells us that he had read (and was quite impressed by) this work. 
${ }^{\text {xvi }}$ Recently, some commentators have argued that Kant's command of English was better than he usually is given credit for (see, e.g., Sanford Budick, Kant and Milton (Harvard University Press, 2010), esp. pp. 53-4). This suggests that Kant might have been able to puzzle his way through Hume's Dialogues Concerning Natural Religion as soon as he could get his hands on a copy (i.e., without waiting for a translation). However, there is some independent evidence that Kant's familiarity with this work postdates the first edition of the Critique of Pure Reason in 1781. Although Kant does not refer to Hume explicitly in his discussion of the physico-theological argument in the Critique of Pure Reason, he does refer to Hume in the corresponding discussion of the Lectures on the Philosophical Doctrine of Religion (see V-Phil-Th/Pölitz, AA 28:1063-71) and certain other passages of these transcribed lectures also suggest familiarity with the Dialogues Concerning Natural Religion. Given that Kant was not fluent in English; given that Kant does not allude to Hume in the discussion of the physico-theological argument in the Critique of Pure Reason; given that he was not averse to referring to Hume in general in the Critique of Pure Reason; given that he does refer to Hume in this context and seems to have been familiar with the Dialogues Concerning Natural Religion by the time of the Lectures on the Philosophical Doctrine of Religion; and given that there is evidence that these lectures were delivered after 1781 (here I am relying on the translator's introduction to the Wood and Clark translation of these lectures, pp. 14-5) it seems to me to be reasonable to infer (in the absence of any countervailing evidence) that Kant was not xvii For a recent discussion of these arguments, see Lawrence Pasternack, "Regulative principles and 'the Wise Author of Nature'," Religious Studies 47.4 (2011): 411-29. 
xviii For an exploration of the kinds of belief in God dealt with in the "Canon of Pure Reason," see Lawrence Pasternack, "Kant's Doctrinal Belief in God," in Oliver Thorndike (ed.), Rethinking Kant: Volume 3 (Cambridge Scholars Publishing, 2010), pp. 200-19.

xix There is some affinity between the issues raised by this claim and those raised in parts of The Only Possible Argument in Support of a Demonstration of the Existence of God (see BDG, AA 2:29).

${ }^{\mathrm{xx}}$ For a general discussion of Kant's use of ought implies can, see Robert Stern, "Does 'Ought' Imply 'Can'? And Did Kant Think It Does?’ Utilitas 16.1 (2004): 42-61. xxi In the Lectures on the Philosophical Doctrine of Religion Kant seems to toy with the idea that we are led to believe in God as a way of rationalizing the sacrifices that morality requires (V-Phil-Th/Pölitz, AA 28:1011-2). The thought seems to be that when faced with a choice between doing one's duty and promoting one's earthly happiness, one can find solace in doing one's duty if one believes in a God who will reward one with eternal beatitude.

xxii Kant seems to attribute a similar role to the postulate of immortality in his 1796 Proclamation of the imminent conclusion of a treaty of perpetual peace in philosophy (VNAEF, AA 8:418-9). This fact (and its relevance to my project in this paper) is discussed in section 4 below. xxiii Kant seems to recognize this possibility in his 1790 Critique of the Power of Judgment (KU, AA 5:450-1). 
${ }^{\text {xxiv }}$ For an assessment of these arguments, see, e.g., Manfred Kuehn, "Kant's

Transcendental Deduction of God's Existence as a Postulate of Pure Practical Reason," Kant-Studien 76 (1985): 1-4; Chin-Tai Kim, "A Critique of Kant's Defense of Theistic Faith," Philosophy Research Archives 14 (1988): 359-69; or Allen Wood, Kant's Moral Religion (Cornell University Press, 1970).

xxv Kant might have thought there is a link between the argument from the Critique of Pure Reason and the argument from the Critique of Practical Reason. For example, in R6103 Kant suggests that perfect happiness is progress toward contentment rather than possession of it (Refl, AA 18:455). This sounds much the same as the assertion in the postulate of immortality argument from the Critique of Practical Reason that holiness is realized in progress toward moral perfection rather than possession of it. A similar but even more explicit suggestion can be found in the $\mathrm{L}_{2}$-Pölitz metaphysics lecture notes: ...happiness consists in progress. In the future world we will thus be in progress either toward happiness or toward misery, but whether this will continue to eternity we cannot at all know. Moral good and evil is never perfect here, it is always progress.

(V-Met-L2/Pölitz, AA 28:593)

And yet another suggestive passage can be found in the Volckmann metaphysics lecture notes (see V-Met/Volckmann, AA 28:447). However, if these passages do contain the beginnings of a link between the Critique of Pure Reason argument and the Critique of Practical Reason argument, the point is not explained in sufficient detail for one to assert with any confidence that Kant really thought such a link might be found. 
${ }^{\text {xxvi }}$ For some recent discussions of these arguments in the secondary literature, see Klaus Düsing, “Das Problem des höchesten Gutes,” Kant-Studien 62 (1972): 5-42; Claus Dierksmeier, Das Noumenon Religion. Eine Untersuchung zur Stellung der Religion im System der praktischen Philosophie Kants (de Gruyter, 1998); Edgard Filho, "Concerning Moral Faith in Kant," The Proceedings of the Twenty-First World Congress of Philosophy 10 (2007): 167-75; Chris W. Surprenant, "Kant's postulate of the immortality of the soul," International Philosophical Quarterly 48.1 (2008): 85-98; Patrick Kain, "Practical Cognition, Intuition, and the Fact of Reason," in Benjamin Lipscomb and James Krueger (eds.), Kant's Moral Metaphysics: God, Freedom, and Immortality (de Gruyter 2010); or Sebastian Gardner, "Kant's Practical Postulates and the Limits of the Critical System," Bulletin of the Hegel Society of Great Britain 63 (2011): 187-215. The general consensus seems to be that Kant's argument is unsuccessful. xxvii There might be an earlier hint of this argument in Kant's Lectures on the Philosophical Doctrine of Religion when he suggests that physico-theology does not give us a determinate concept of God but rather only teaches us that there is "a very great and immeasurable being" (V-Phil-Th/Pölitz, AA 28:1071): in this passage, Kant suggests that morality is needed to go further in our cognition of God.

xxviii THE CONTENTS OF THIS NOTE HAVE BEEN DELETED BECAUSE THEY CONTAIN POTENTIALLY IDENTIFYING INFORMATION. xxix THE CONTENTS OF THIS NOTE HAVE BEEN DELETED BECAUSE THEY CONTAIN POTENTIALLY IDENTIFYING INFORMATION. 
${ }^{\mathrm{xxx}}$ For example, at KU, AA 5:460-1, 466 and 469 the postulate of immortality is simply glossed over without argument (in stark contrast to the treatment of the postulate of the existence of God, which, as noted above, is discussed at length and even given its own section).

${ }^{x x x i}$ Here is the quotation from the footnote: "[t]hat is, the proposition, "Make the highest possible good in this world your own final end," is a synthetic proposition a priori which is introduced by the moral law itself..." (RGV, AA 6:07n, my emphasis). xxxii THE CONTENTS OF THIS NOTE HAVE BEEN DELETED BECAUSE THEY CONTAIN POTENTIALLY IDENTIFYING INFORMATION. xxxiii In the $\mathrm{K}_{2}$-Heinze passage Kant introduces also the argument that immortality of the soul is needed in order fully to develop our moral predispositions (V-Met-K2/Heinze, AA 28:765-6). This seems to be a paraphrase of the argument for the postulate of immortality that we find in the Critique of Practical Reason.

xxxiv For a small cross section of similar reflections from this period, see: R2503 (Refl, AA 16:395-6), R2793 (Refl, AA 16:513-5), R6349 (Refl, AA 18:674), R6351 (Refl, AA 18:677-8), R6356 (Refl, AA 18:681-2), R6358 (Refl, AA 18:682-5) and R7316 (Refl, AA 19:313-5).

xxxv THE CONTENTS OF THIS NOTE HAVE BEEN DELETED BECAUSE THEY CONTAIN POTENTIALLY IDENTIFYING INFORMATION. xxxvi Relying here on the translator's introduction in the Cambridge blue series. xxxvii THE CONTENTS OF THIS NOTE HAVE BEEN DELETED BECAUSE THEY CONTAIN POTENTIALLY IDENTIFYING INFORMATION. 